\title{
Characterization of cultivable endophytic fungi from the medicinal plant Senna reticulata (Willd.) H. S. Irwin \& Barneby
}

\section{Caracterização de fungos endofíticos cultiváveis da planta medicinal Senna reticulata} (Willd.) H. S. Irwin \& Barneby

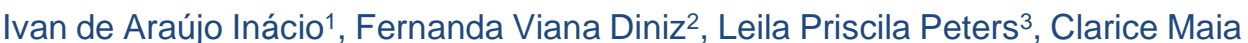
Carvalho 4

\section{ABSTRACT}

The objective of this work was to characterize the endophytic fungi community of the medicinal plant $S$. reticulata. Vegetable tissue samples from $S$. reticulata plants, stems and leaves, were collected, washed and disinfected by immersion in $70 \%$ etanol, $2 \%$ sodium hypochlorite, $70 \%$ alcohol, and washing in sterile distilled water. The samples were fragmented and inoculated in PDA and Sabouraud culture media, with and without plant extract. After inoculation, the plates were incubated at $18^{\circ} \mathrm{C}$ or $28^{\circ} \mathrm{C}$ for 30 days. The isolated fungi were characterized in terms of their macromorphology and micromorphology. A total of $309 \mathrm{~S}$. reticulata endophytic fungi, 178 stem fungi and 131 leaf fungi, were isolated. A greater number of isolates was obtained in plant I, totaling 194. Sabouraud medium with plant extract at $18^{\circ} \mathrm{C}$, were the best conditions for isolation of endophytic fungi of S. reticulata. 27 morphospecies were identified, distributed in ten genera, Phomopsis (32.4\%), Penicillium (13\%), Aspergillus (5.8\%), Acremonium (2.6\%), Colletotrichum (1.6\%), Curvularia (1.6\%), Alternaria (0.3\%), Trichoderma $(0.3 \%)$, Cladosporium (0.3\%) and Xylaria (0.3\%). Senna reticulata has a diverse community of endophytic fungi, with Phomopsis as dominant. This is the first report of endophytic fungi from the medicinal plant Senna reticulata.

Keywords: Pasture killer; Medicinal plants; Phomopsis.

\section{RESUMO}

O objetivo deste trabalho foi caracterizar a comunidade de fungos endofíticos da planta medicinal $S$. reticulata. Amostras de caule e folhas de $S$. reticulata foram coletadas, lavadas e desinfetadas por imersão em etanol 70\%, hipoclorito de sódio $2 \%$, álcool $70 \%$ e lavagem em água destilada estéril. As amostras foram fragmentadas e inoculadas em meios de cultura BDA e Sabouraud, com e sem extrato vegetal. Após a inoculação, as placas foram incubadas a $18{ }^{\circ} \mathrm{C}$ ou $28 \stackrel{\circ}{\circ}$ por 30 dias. Os fungos isolados foram caracterizados quanto à macromorfologia e micromorfologia. Um total de 309 fungos endofíticos de S. reticulata, 178 fungos do caule e 131 fungos foliares foram isolados. Um maior número de isolados foi obtido na planta I, totalizando 194. O meio Sabouraud com extrato da planta a 18 oC, foram as melhores condições para o isolamento dos fungos endofíticos de $S$. reticulata. Foram identificadas 27 morfoespécies, distribuídas em dez gêneros, Phomopsis (32,4\%), Penicillium (13\%), Aspergillus (5,8\%), Acremonium (2,6\%), Colletotrichum (1,6\%), Curvularia (1,6\%), Alternaria (0,3\%), Trichoderma $(0,3 \%)$, Cladosporium $(0,3 \%)$ e Xylaria $(0,3 \%)$. Senna reticulata possui uma comunidade diversificada de fungos endofíticos, com Phomopsis como dominante. Este é o primeiro relato de fungos endofíticos da planta medicinal Senna reticulata.
${ }^{1}$ Graduação em Engenharia Florestal pela Universidade Federal do Acre

Laboratório de Microbiologia da Universidade Federal do Acre

E-mail:

ivsaraujoinacio@gmail.com

${ }^{2}$ Doutoranda pelo Programa de Pós-graduação em Produção vegetal da Universidade Federal do Acre

Laboratório de Microbiologia da Universidade Federal do Acre

E-mail: fvianadiniz@gmail.com

3Pós-doutoranda (PNPD) pelo programa de Ciência, Inovação e Tecnologia para a Amazônia da Universidade Federal do Acre

Laboratório de Microbiologia da Universidade Federal do Acre

E-mail: leilappeters@gmail.com

${ }^{4}$ Doutora em Biotecnologia pela Universidade Federal do Amazonas

Laboratório de Microbiologia da Universidade Federal do Acre

E-mail:

claricemaiacarvalho@gmail.com

Palavras-chaves: Mata-pasto; Plantas medicinais; Phomopsis 


\section{INTRODUCTION}

Senna reticulata (Willd.) H. S. Irwin \& Barneby is a pioneer Amazonian species, found in abundance in lowland regions, river beds and other environments that are subject to flooding (PAROLIN, 2005). However, the species also grows in upland regions, colonizing sites above $25 \mathrm{~m}$ from the river level, where it occurs more frequently in highly sedimented soils (PAROLIN et al., 2002). It belongs to the Leguminosae family and has leaves composed of 8 - 14 pairs of leaves that have an oval shape. The flowers are large, yellow and pollinated by insects. The fruits are long and dry. They have many branches scattered irregularly (PAROLIN, 2005).

Due to its great competitive character, $S$. reticulata is popularly known in the Amazon for pasture killer (PAROLIN, 2003). It can grow up to $4 \mathrm{~m}$ in the first months after establishment in the soil, at $12 \mathrm{~m}$ as an adult. It is usually found measuring between 4 and $8 \mathrm{~m}$ in height, with a diameter at chest height (DBH) of $5.2 \mathrm{~cm}$ (PAROLIN, 1998). Characteristically, red ants build nests on $S$. reticulata and attack all intruders very aggressively, especially in the Costa do Catalão, where caterpillars can reduce the leaf area of the seedlings by $20 \%$ (PAROLIN, 2001). The plant species is rich in secondary compounds, and it is used to treat intestinal infections, fungal diseases (PAROLIN, 2001), antirheumatic and dermatitis (PAROLIN, 2001; LIZCANO, 2010).

Study of the chemical constituents of $S$. reticulata, there are six anthraquinones, 1,8dihydroxy-3-methylanthroquinone (chrysofanol), 1,8-dihydroxy-3-methyl-6-metaxyanthraquinone (fisciona), 3-carbinol-1, 8-dihydroxyanthraquinone, 1,3,8-trihydroxyanthraquinone, 1,6,8trihydroxy-3-metaxyanthraquinone (lunatin), 1,6,8-trihydroxy-3-methylanthraquinone (emodine), $\beta$-sitosterol and stigmasterol steroids, $\alpha$ and $\beta$ amirine triterpenes and the campferol flavonoid and the chrysofanol biantrone (SANTOS; SILVA, 2008). The great distribution, abundance and ethnobotany, aroused interest in studies on the biological activities of this plant. The leaf of $S$. reticulata has antioxidant activities (LIZCANO et al., 2010; MATULEVICH-PELÁEZ et al., 2017) and reduced blood glucose rates in diabetic rats (CRISTANCHO et al., 2009). The root can be used to treat malaria (VIGNERON et al., 2005), and hydroethanolic extracts of the bark and leaf showed antifungal activity against the fungi Microsporum canis, Trichophyton mentagrophytes and Trichophyton rubrum (OLIVEIRA, 2009). 
Plants live in constant association with microorganisms, which can be beneficial or harmful. A portion of these microorganisms, mainly bacteria and fungi, inhabit the interior of these plants, called endophytes. These organisms internally colonize plant tissues at some point in the life cycle, without causing apparent damage (DE SILVA et al., 2019). This association can confer several advantages to the plant, such as the decrease in herbivory, the increase of tolerance to abiotic stresses and the control of pathogenic microorganisms (ZHANG et al., 2006).

In addition to research on biological activity in plants, endophytic microorganisms from plant tissues are interest to the scientific community, especially because of the potential in agriculture and industry, in the production of antibiotics and other secondary metabolites of pharmacological interest, such as the anti-tumor taxol (STIERLE et al., 1993), and also as pest inhibiting agents (AHMAD et al., 2020) and pathogens (PETERS et al., 2020). Thus, microorganisms and plants can be studied in the search for new biologically active substances.

Despite this relevance, no study on the endophytic fungi community of Senna reticulata was found in the literature. Thus, the objective of this work was to describe the community of cultivable endophytic fungi of the medicinal plant of Senna reticulata.

\section{MATERIAL AND METHODS}

\section{Plant material}

Leaf and stem samples from two Senna reticulata plants were collected at the Zoobotanic Park of the Federal University of Acre located in the city of Rio Branco, Acre, Brazil (Figure 1).

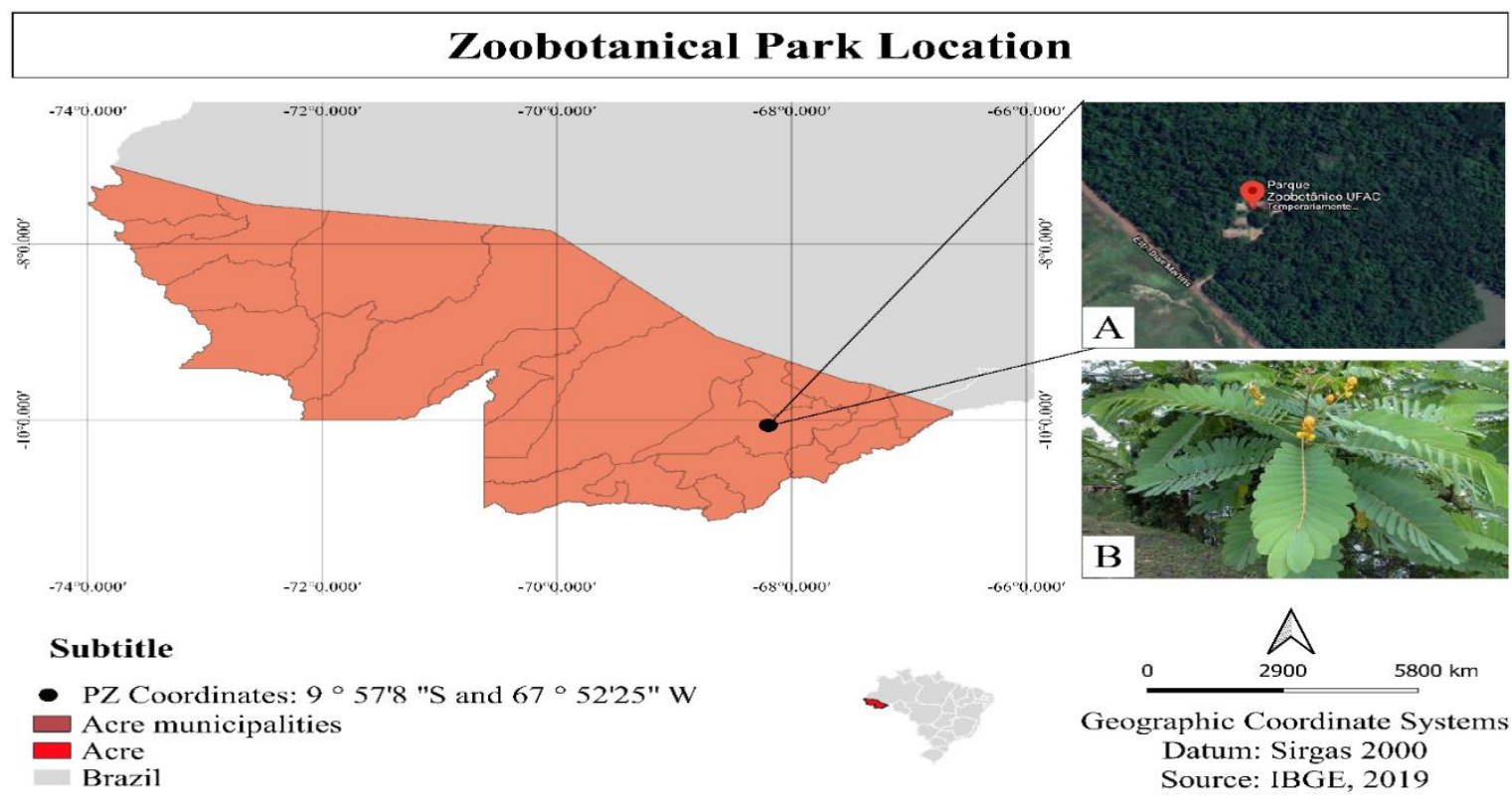

Figure 1. Location map of the S. reticulata collection point. A) Satellite image of the Zoobotanical Park. B) Image of the $S$. reticulata plant. 


\section{Isolation of endophytic fungi}

Senna reticulata leaf and stem were washed with a sponge and detergent in running water to remove solid residues and epiphytic microorganisms. After washing, the material underwent superficial disinfection by immersion in $70 \%$ ethanol ( $1 \mathrm{~min}), 2 \%$ sodium hypochlorite (4 $\mathrm{min}$ ), 70\% alcohol (30 sec) and washing in sterile distilled water (1 min) three times. The disinfected plant material was cut into fragments of $5 \mathrm{~mm}$ in diameter and inoculated into a Petri dish containing Potato-Dextrose-Agar-PDA, PDA + 10\% plant extract, Sabouraud-SDA, SDA + plant extract a 10\%, all supplemented with chloramphenicol antibiotics $\left(100 \mu \mathrm{g} \mathrm{mL}^{-1}\right)$, to inhibit bacterial growth, and incubated at $18^{\circ} \mathrm{C}$ or $28^{\circ} \mathrm{C}$ for 30 days. To prepare the PDA + extract medium, $500 \mathrm{~mL}$ of $200 \mathrm{~g}$ of potato infusion was added to $500 \mathrm{~mL}$ of plant extract, and for the preparation of the SDA+extract medium $500 \mathrm{~mL}$ of water, and the reagents used in the preparation of each culture medium were solubilized (ARAÚJO et al., 2010).

The fungal colonies with distinct characteristics according to macroscopic observations (color, texture and growth characteristics in culture medium) were purified using the streak technique by depletion in Petri dishes containing the PDA culture medium, and incubated for $48 \mathrm{~h}$. After the purity of the colonies was confirmed, the isolates were inoculated into tubes containing PDA medium (ARAÚJO et al., 2010), and the fungi were preserved in distilled water (CASTELLANI, 1963) and mineral oil (BUELL; WESTON, 1947).

\section{Morphological characterization}

For the macromorphological characterization, the fungi were grouped into morphospecies according to the characteristics of the colony, such as color, texture and pigment production. One representative of each morphospecies was used for micromorphological identification. For this, microculture was carried out, the fungi were inoculated in $1 \mathrm{~cm}^{2}$ cubes of PDA and covered with coverslips, inside Petri dishes. The plates were incubated at room temperature for 7 days for mycelial growth and the coverslips stained with lactophenol blue for visualization of reproductive structures under an optical microscope (LACAZ et al., 1998; BARNETT; HUNTER, 1999).

\section{Data analysis}

The relative frequency of isolated endophytic fungi was calculated by the number of fungi per tissue, culture medium, temperature or genus divided by the total number of isolated fungi, multiplied by one hundred, in the Excel program. GraphPad Prism 5.0 was 
used to make figures and QGIS was used for the map. Principal Component Analysis (PCA) was performed using the software Statistica 2.0 to evaluate the influence of culture media on the isolation of fungal endophytes.

\section{RESULTS}

A total of 309 endophytic fungi of Senna reticulata, 178 of stem and 131 of leaf were isolated (Table 1). A greater number of fungi was isolated from individual I, collected in January, 194 isolates, and the tissue stem with the largest number (110). From individual II, 115 fungi were isolated, and the stem had a greater number of isolates than leaf, with 68 fungi (Figure 1).

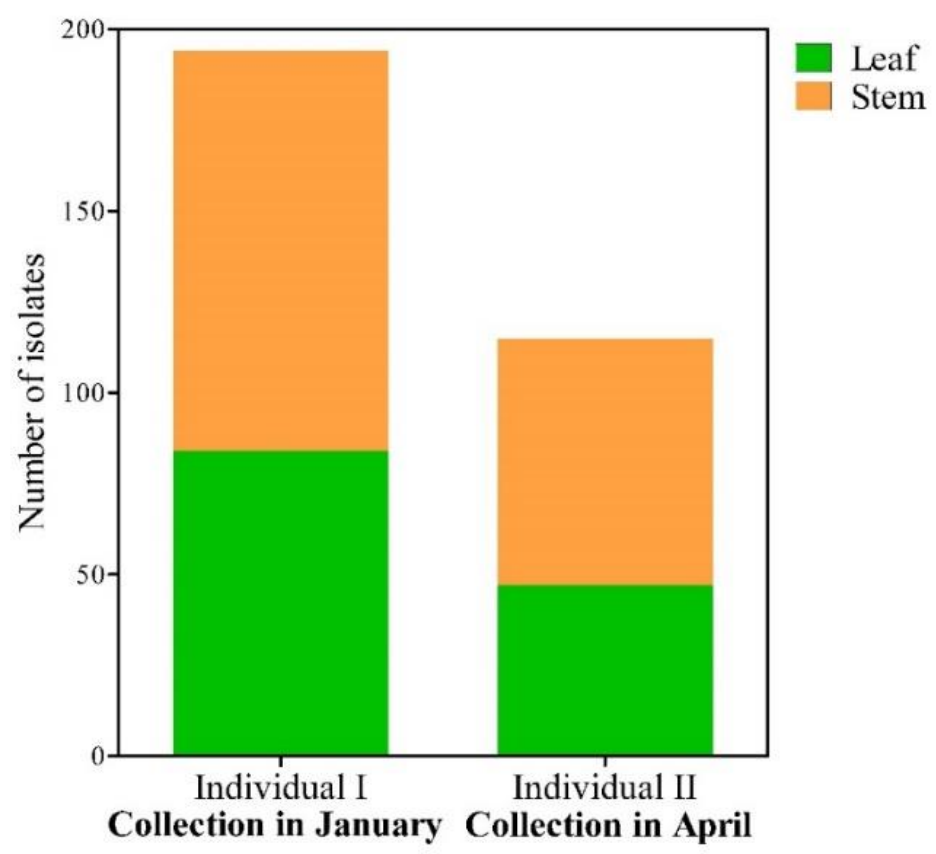

Figure 1. Number of isolates of $S$. reticulata endophytic fungi per individual and plant tissue.

The greatest fungal growth was with the addition of the plant extract to conventionally used media, and the SDA + extract medium presented the highest amount of isolates, with 98 fungi. About temperature, $18^{\circ} \mathrm{C}$ had the best result for isolation of $\mathrm{S}$. reticulata endophytic fungi with 169 isolates (Table 1). 
DOI: 10.18605/2175-7275/cereus.v13n2p42-58
INÁCIO, I. A.; DINIZ, F. V.; PETERS, L. P.; CARVALHO, C. M.

Characterization of cultivable endophytic fungi from the medicinal plant Senna reticulata (Willd.) H. S. Irwin \& Barneby

Table 1. Number and relative frequency (RF) percentages of fungal endophyte isolated from Senna reticulata according to the plant tissue, culture medium and temperature.

\begin{tabular}{|c|c|c|c|c|c|c|c|c|c|c|}
\hline \multirow[b]{2}{*}{ Genus } & \multicolumn{2}{|c|}{ Plant Tissue } & \multicolumn{4}{|c|}{ Culture Medium } & \multicolumn{2}{|c|}{ Temperature } & \multirow[b]{2}{*}{$\mathbf{T}$} & \multirow[b]{2}{*}{$\mathrm{RF}(\%)$} \\
\hline & Leaf & Stem & PDA & $\begin{array}{l}\text { PDA+ } \\
\text { extract }\end{array}$ & SDA & $\begin{array}{c}\text { SDA + } \\
\text { extract }\end{array}$ & $18^{\circ} \mathrm{C}$ & $28^{\circ} \mathrm{C}$ & & \\
\hline Phomopsis & 35 & 65 & 15 & 23 & 13 & 49 & 52 & 48 & 100 & 32.4 \\
\hline Penicillium & 20 & 20 & 12 & 5 & 13 & 10 & 23 & 17 & 40 & 13.0 \\
\hline Aspergillus & 8 & 10 & 5 & 3 & 5 & 5 & - & 18 & 18 & 5.8 \\
\hline Acremonium & 3 & 5 & - & 3 & 3 & 2 & 5 & 3 & 8 & 2.6 \\
\hline Colletotrichum & 3 & 2 & - & 3 & - & 2 & - & 5 & 5 & 1.6 \\
\hline Curvularia & - & 5 & - & - & 5 & - & 2 & 3 & 5 & 1.6 \\
\hline Alternaria & - & 1 & - & - & - & 1 & 1 & - & 1 & 0.3 \\
\hline Trichoderma & 1 & - & - & - & - & 1 & 1 & - & 1 & 0.3 \\
\hline Cladosporium & - & 1 & - & 1 & - & - & 1 & - & 1 & 0.3 \\
\hline Xylaria & 1 & - & - & 1 & - & - & 1 & - & 1 & 0.3 \\
\hline Mycelia sterilia & 60 & 69 & 48 & 19 & 34 & 28 & 83 & 46 & 129 & 41.8 \\
\hline Total & 131 & 178 & 80 & 58 & 73 & 98 & 169 & 140 & 309 & 100 \\
\hline RF (\%) & 42.4 & 57.6 & 25.9 & 18.8 & 23.6 & 31.7 & 54.7 & 45.3 & & \\
\hline
\end{tabular}

The isolated fungi were classified into 133 morpho-species, and 27 identified morphospecies distributed in ten genera, Phomopsis (32.4\%), Penicillium (13\%), Aspergillus (5.8\%), Acremonium (2.6\%), Colletotrichum (1.6\%), Curvularia (1.6\%), Alternaria (0.3\%), Trichoderma (0.3\%), Cladosporium (0.3\%) and Xylaria $(0.3 \%)$. The other morphospecies were not identified because they do not have reproductive structures, considered sterile mycelium (41.8\%)

A

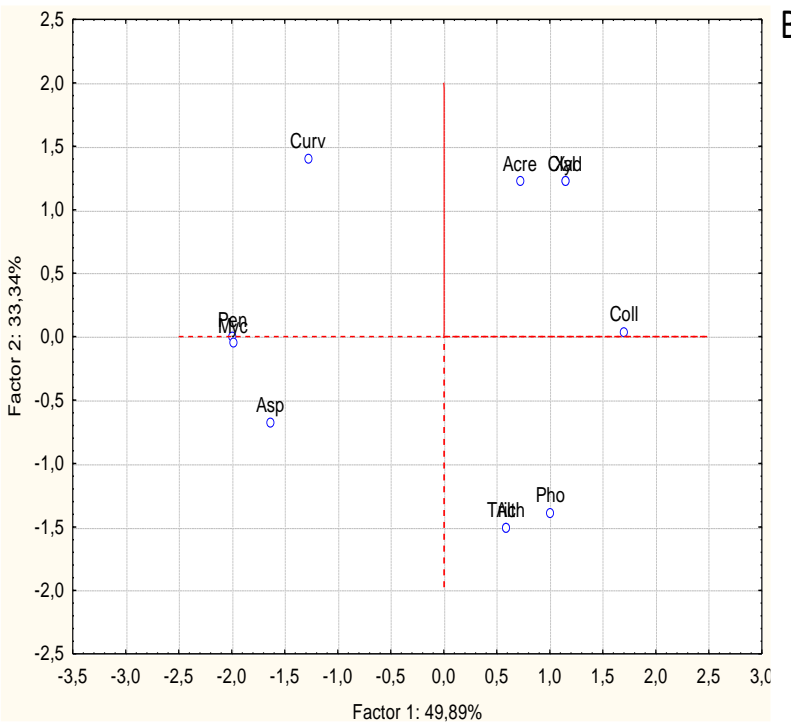

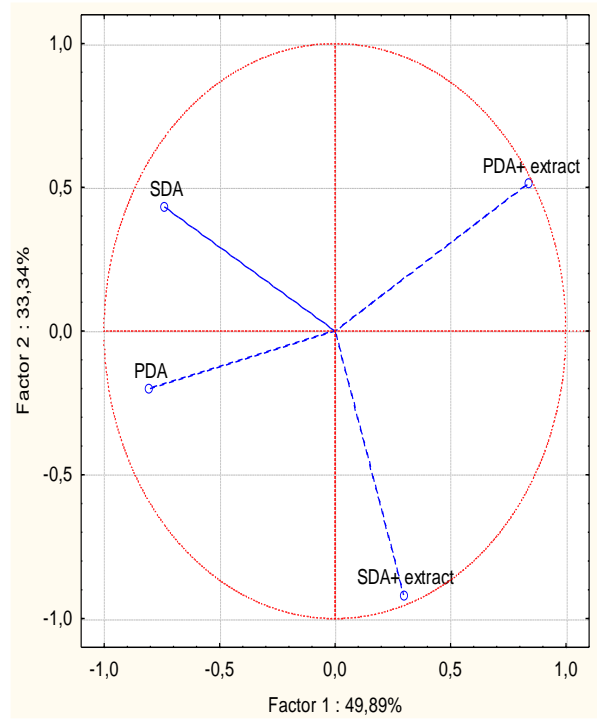

Figura 1. Principal component analysis (PCA) of media effect (PDA, PDA+extract, SDA and SDA+extract) on endophytic fungi isolation from $S$. reticulata. (A) Discriminations of endophytic fungi isolated on different media; (B) Loading plot of media for the first two principal components, PC1 and PC2. 


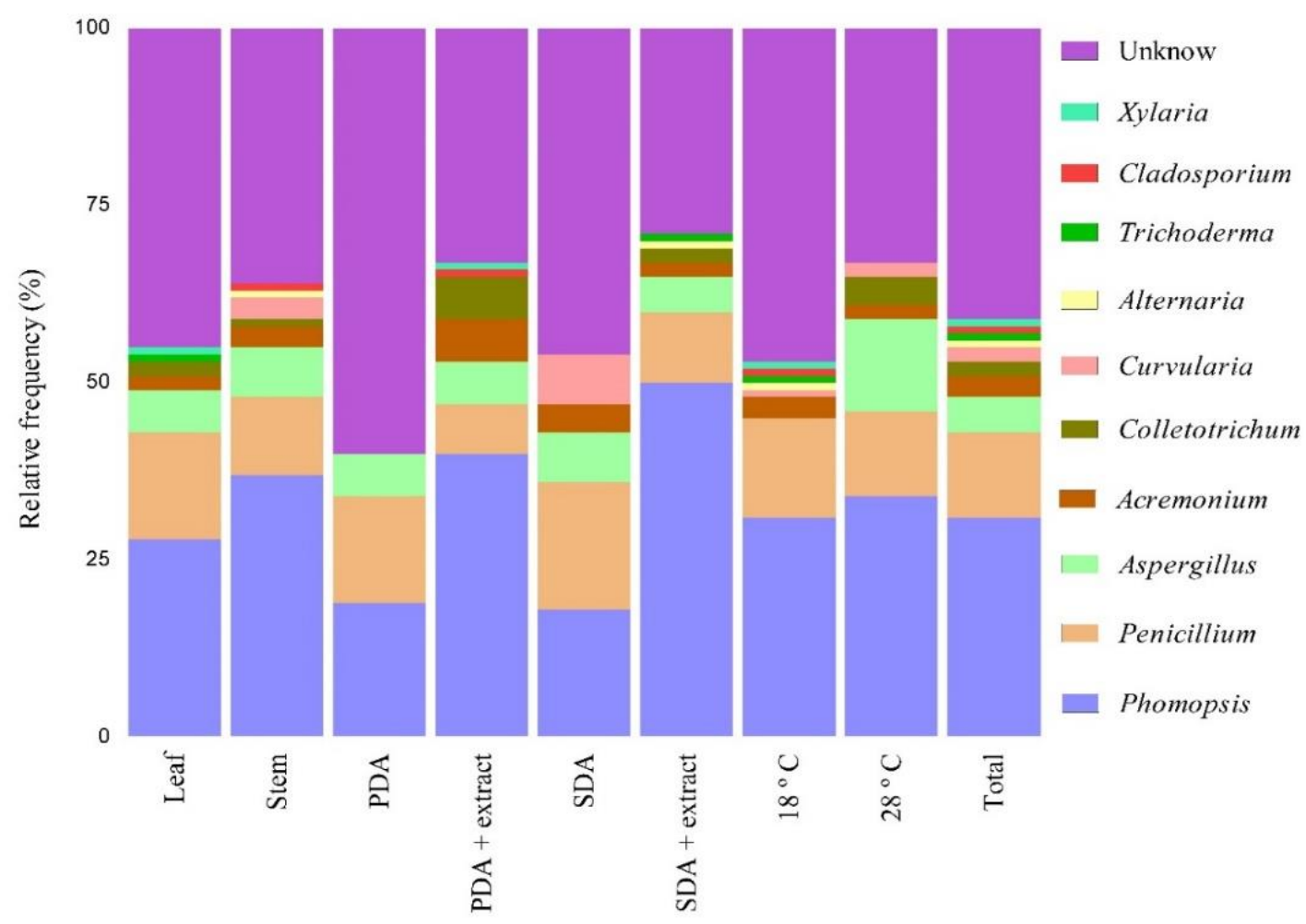

Figure 2. Relative frequency of genera of endophytic fungi of $S$. reticulata distributed vegetable tissue, culture medium and temperature.

The genera Phomopsis, Penicillium and Aspergillus grew in all culture media, however Curvularia, Cladosporium, Xylaria, Alternaria and Trichoderma were specific to a single culture medium (Figure 2A). Based on the PCA results, the Phomopsis genus was more abundant in the SDA + extract medium, while the Penicillium genus was more abundant in the non-extract medium (SDA and PDA) (Figure 1). The genera Colletotrichum, Curvularia, Trichoderma, Cladosporium, Alternaria and Xylaria were more abundant or only isolated in media with plant extract. The Aspergillus genus was more abundant in three media: PDA, SDA and SDA + extract. The Acremonium genus was more abundant in SDA and PDA + extract (Figure 1).

Phomopsis, Penicillium, Acremonium and Curvularia grew at $18 \stackrel{\circ}{\circ}$ and $28 \stackrel{\circ}{\circ}$, the other fungi were specific for temperature (Figure 2B). Trichoderma and Xylaria were specific for leaf, and Curvularia, Alternaria and Cladosporium for stem, the other genera proved to be generalists (Figure $2 \mathrm{C}$ ). 
A

Figure 3. Venn diagram showing the effect of experimental conditions on the isolation of endophytic fungi isolated from $S$. reticulata. A) Genera isolated according to the culture medium used (Co: Colletotrichum; Ph: Phomopsis; Xy: Xylaria; Pe: Penicillium; As: Aspergillus; Ac: Acremonium; Fu: Fusarium; Tr: Trichoderma; Cl: Cladosporium; $\mathrm{Cu}$ : Curvularia; Al: Alternaria). B) Genera isolated according to temperature. C) Genera isolated according to the plant tissue.

\section{DISCUSSION}

Senna reticulata has been shown to harbor important genera of endophytic fungi. The isolation of the endophytic community of a plant can be affected by numerous variables, such as the time of collection of plant samples, as observed in this work, given the greater fungal recovery of individual I, collected in January in the amazon winter. In addition, in this study greater isolation of stem fungi was observed, which may be related to the presence of characteristic tissue substances such as - bisabolol, which has a protective function to the fungal community that colonizes it (SIEBER; DOWORTH, 1994; OTERO et al., 2002).

As for the experimental conditions, there were more fungi isolations in Sabouraud medium with the addition of the plant extract and at a temperature of $18{ }^{\circ} \mathrm{C}$. These data differ from most studies with endophyte isolation, which use only PDA medium and temperatures above $20^{\circ} \mathrm{C}$ as ideal conditions for isolation (LIANG et al., 2012; YADAV et al., 2014). This fact demonstrates that there is no single ideal condition for the isolation of endophytic microorganisms, and that it is necessary to use different nutritional sources, different temperatures, and even variation in the $\mathrm{pH}$ of the medium, to start fungal growth (DE FREITAS SIA et al., 2013). 
Thus, fungi that may be in latency will receive the necessary stimulus to start growth, with greater knowledge from the endophytic community (CARNAUBA et al., 2007; SIA, 2012; DA SILVA et al., 2020). Other aspects that also act in the recovery of the endophytic community are: genetic quality, plant age, geographical distribution and environmental conditions (FAETH; FAGAN, 2002; OKI et al., 2009; HARDOIM et al., 2015).

Based on the morphological characteristics of the isolated fungi, it was possible to organize them into ten genera, Phomopsis, Penicillium, Aspergillus, Acremonium, Colletotrichum, Curvularia, Alternaria, Trichoderma, Cladosporium and Xylaria. Phomopsis was the genus with the highest frequency of isolation, totaling $32.4 \%$. This genus is often isolated as an endophyte from Amazonian plants like Carapa guianenses and Euterpe precatoria (FERREIRA et al., 2015; PETERS et al., 2020). Metabolites of fungi of the genus Phomopsis have antimicrobial activity, inhibition of the growth of Trypanosoma cruzi amastigotes and antiviral action against the yellow fever virus (FERREIRA et al., 2015). It also has environmental applications, due to the degradation of $\mathrm{N}$-heterocyclic indole xenobiotics and 4-hydroxybenzoic acid (CHEN et al., 2011; CHEN et al., 2013).

Penicillium and Aspergillus were isolated with a frequency of 13 and $5.8 \%$, respectively. Both are similar genera in terms of ecological characteristics, as they are fungi with easy dissemination in the environment and can be recovered from plants, soil, water, air, among others (BENOIT et al., 2013; CRUZ et al., 2013). As endophytes, it has provided important biotechnological applications in different areas of knowledge. In agriculture, Penicillium citrinum and Aspergillus terreus provided induction of disease resistance, and growth promotion in sunflower (Helianthus annuus L.) (WAQAS et al., 2015). In health, Penicillium has shown antimicrobial, antimalarial and antituberculosis activity (INTARAUDOM et al., 2013; KOREJO et al., 2014). As for the genus Aspergillus, an important pharmaceutical product is produced from A. terreus, called lovastatin. This compound is highly required as it is a medication used to control cholesterol in humans (RAGHUNATH et al., 2012).

Acremonium was isolated with $2.6 \%$ frequency, and this is a cultivable endophytic fungus with biotechnological applications. This genus produces important enzymes, such as cellulases and hemicellulases in the degradation of lignocellulosic residues for the purpose of ethanol production (ALMEIDA et al., 2011). In agriculture, this endophyte has produced active compounds, such as gliotoxin, which acts in the biocontrol of Pythium myriotylum, a 
causal agent of soft rot in ginger, in addition to being efficient against the nematode Meloidogyne incognita (YAN et al., 2011; ANISHA; RADHAKRISHNAN, 2015). Antimicrobial activity against human pathogens was observed in Acremonium isolated from Sesbania grandiflora (L.) (POWTHONG et al., 2013).

Colletotrichum and Curvularia were isolated at the same frequency of $1.6 \%$ each. Colletotrichum is a genus of great importance in agriculture because it causes diseases in plants and economic damage, as is the case of anthracnose in papaya (RIBEIRO et al., 2016). However, strains isolated as endophytes of this genus have shown benefits to the host plant as promoting plant growth by transferring phosphorus to Arabidopsis shoots and participating in the production of indole-3-acetic acid (HIRUMA et al., 2016; NUMPONSAK et al., 2018). Curvularia can also become a phytopathogen, mainly in seeds and trigger economic losses. However, compounds isolated from endophytic strains have shown that fungi of the genus Curvularia have metabolites with antimicrobial, antioxidant and acetylcholinesterase inhibitor activities (SILVA et al., 2014; KAANICHE et al., 2019).

Alternaria, Trichoderma, Cladosporium and Xylaria were the four least frequent genera in the isolation of $S$. reticulata, with only $0.3 \%$ each. Both are commonly isolated as endophytes from plants such as Euterpe precatoria, Avicennia officinalis, Hevea brasiliensis and H. guianensis (CHAVERRI et al., 2011; RANGANATHAN; MAHALINGAM, 2019; PETERS et al., 2020). Alternaria has been the focus of research in the production of secondary metabolites due to its composition by steroids, terpenoids, pyranones, quinones and phenolics (LOU et al., 2013). Some metabolites are for medicinal purposes, with antifungal and antidiabetic activity, and others for agricultural purposes, with potential insecticide against Spodoptera litura (SINGH et al., 2012; CHAGAS et al., 2013; GOVINDAPPA et al., 2015).

Trichoderma is one of the most studied fungal genera in the literature due to its biotechnological potential for industrial, pharmaceutical, environmental and agricultural areas (SCHUSTER et al., 2010; MACHADO et al., 2012). Secondary metabolites of Trichoderma have promoted antifungal and anticancer activity (MING et al., 2012; SHENTU et al., 2014). In agriculture, the main focus is the biocontrol of pests and diseases, which has had an antagonistic effect for pepper moth (Duponchelia fovealis) and black rot in cocoa (Phytophthora palmivora) (HANADA et al., 2008; AMATUZZI et al., 2018).

Cladosporium have promoted sustainable ecological technology by mediating the 
biological synthesis of silver nanoparticles (AgNPS) with anti-diabetic and anti-alzheimer activity (POPLI et al., 2018). In addition, it has antitumor action due to the production of taxol and antimicrobial by the production of plumbago (ZHANG et al., 2009; VENKATESWARULU et al., 2018). Xylaria is known as a wood decomposing fungus (PHOTITA et al., 2001), but when isolated as an endophyte it produces important substances such as griseofulvin, diketopiperazines and cytochalasins with antifungal, antioxidant and anticholinesterase activities (CHAPLA et al., 2018).

Therefore, it was possible to observe the presence of fungi with several biotechnological applications, which are associated with the medicinal plant S. reticulata. In this way, future studies should focus on bioprospecting these strains for industrial, pharmaceutical or agricultural purposes.

\section{CONCLUSIONS}

There is a wide variety of endophytic fungi in Senna reticulata, these being more frequent in stem, more isolated in Sabouraud medium with plant extract at $18{ }^{\circ} \mathrm{C}$, and the genus Phomopsis is dominant. This is the first report from the endophytic fungi community of the medicinal plant Senna reticulata.

\section{ACKNOWLEDGMENT}

The authors would like to thank the Brazilian institutions "Coordenação de Aperfeiçoamento de Pessoal de Nível Superior (CAPES) " and "Conselho Nacional de Desenvolvimento Científico e Tecnológico (CNPQ) " for the scholarship.

\section{REFERENCES}

AMATUZZI, R. F.; CARDOSO, N.; POLTRONIERI, A. S.; POITEVIN, C. G.; DALZOTO, P.; ZAWADENEAK, M. A.; PIMENTEL, I. C. Potential of endophytic fungi as biocontrol agents of Duponchelia fovealis (Zeller) (Lepidoptera: Crambidae). Brazilian Journal of Biology, v. 78, n. 3, p. 429-435, 2018.

ANISHA, C.; RADHAKRISHNAN, E. K. Gliotoxin-producing endophytic Acremonium sp. from Zingiber officinale found antagonistic to soft rot pathogen Pythium myriotylum. Applied biochemistry and biotechnology, v. 175, n. 7, p. 3458-3467, 2015. 
ARAÚJO, W. L.; LACAVA, P. T.; MARCO, J.; LIMA, A. O. D. S.; SOBRAL, J. K.; AZEVEDO, J. L. D.; PIZZIRANI-KLEINER, A. A. Guia prático: Isolamento e caracterização de microrganismos endofíticos. Piracicaba: Copiadora "Luiz de Queiroz", 2010, 167 p.

BARNETT, H. L.; HUNTER, B. B. Illustrated genera of imperfect fungi. St. Paul: APS, 1999, $218 \mathrm{p}$.

BENOIT, I.; MALAVAZI, I.; GOLDMAN, G. H.; BAKER, S. E.; de VRIES, R. P. Aspergillus: genomics of a cosmopolitan fungus. In: HORWITZ, B. A.; MUKHERJEE, P. K.; MUKHERJEE, M.; KUBICEK, C. P. Genomics of soil-and plant-associated fungi. Springer, Berlin, Heidelberg, 2013. p. 89-126.

BUELL, C. B.; WESTON, W. H. Application of the mineral oil conservation method to maintaining collections of fungous cultures. American Journal of Botany, v. 34, n. 10, p. 555-561, 1947.

CARNAÚBA, J.P.; SOBRAL, M.F.; AMORIM, E.P. Avaliação de diferentes meios de cultura na esporulação de Scytalidium lignicola. Summa Phytopathology, v.33, p.199 - 200, 2007.

CASTELLANI, A. The "water cultivation" of pathogenic fungi. The Journal of Tropical Medicine and Hygiene, v. 66, n.1, p. 283-4, 1963.

CHAGAS, F. O.; DIAS, L. G.; PUPO, M. T. A mixed culture of endophytic fungi increases production of antifungal polyketides. Journal of Chemical Ecology, v. 39, n. 10, p. 13351342, 2013.

CHAPLA, V. M.; ZERAIK, M. L.; CAFEU, M. C.; SILVA, G. H.; CAVALHEIRO, A. J.; BOLZANI, V. S.; YOUNG, M. C. M.; PFENNING, L. H.; ARAUJO, A. R. Griseofulvin, Diketopiperazines and Cytochalasins from Endophytic Fungi Colletotrichum crassipes and Xylaria sp., and Their Antifungal, Antioxidant and Anticholinesterase Activities. Journal of the Brazilian Chemical Society, v. 29, n. 8, p. 1707-1713, 2018.

CHAVERRI, P.; GAZIS, R. O. Linking ex planta fungi with their endophytic stages: Perisporiopsis, a common leaf litter and soil fungus, is a frequent endophyte of Hevea spp. and other plants. Fungal Ecology, v. 4, n. 1, p. 94-102, 2011.

CHEN, Y.; PENG, Y.; DAI, C. C.; JU, Q. Biodegradation of 4-hydroxybenzoic acid by Phomopsis liquidambari. Applied Soil Ecology, v. 51, p. 102-110, 2011.

CHEN, Y.; XIE, X. G.; REN, C. G.; DAI, C. C. Degradation of N-heterocyclic indole by a novel endophytic fungus Phomopsis liquidambari. Bioresource technology, v. 129, p. 568574, 2013.

CRISTANCHO, L. S.; MEJÍA, G. I.; AGUDELO, S. M. A. Estudio preliminar de los efectos hipoglicemiantes de Senna reticulata en ratas diabéticas. Biosalud, v. 8, p. 29-36, 2009.

CRUZ, R.; SANTOS, C.; SILVA DE LIMA, J.; APARECIDA MOREIRA, K.; MARIA DE SOUZA-MOTTA, C. Diversity of Penicillium in soil of Caatinga and Atlantic Forest areas of 
Pernambuco, Brazil: an ecological approach. Nova Hedwigia, v. 97, n. 3- 4, p. 543-556, 2013.

DA SILVA, S. S.; COSTA, M. B. S.; DE SOUZA, A. Q. L.; CARNEIRO, W. S. S.; DE OLIVEIRA, C. M. Isolation and identification of endophytic fungi of Passovia stelis (Loranthaceae). Brazilian Applied Science Review, v. 4, n. 3, p. 1262-1270, 2020.

DE ALMEIDA, M. N.; GUIMARÃES, V. M.; BISCHOFF, K. M.; FALKOSKI, D. L.; PEREIRA, O. L.; GONÇALVES, D. S.; DE REZENDE, S. T. Cellulases and hemicellulases from endophytic Acremonium species and its application on sugarcane bagasse hydrolysis. Applied biochemistry and biotechnology, v. 165, n. 2, p. 594-610, 2011.

DE FREITAS SIA, E.; MARCON, J.; LUVIZOTTO, D. M.; QUECINE, M. C.; TSUI, S.; PEREIRA, J. O.; PIZZIRANI-KLEINER, A. A.; AZEVEDO, J. L. Endophytic fungi from the Amazonian plant Paullinia cupana and from Olea europaea isolated using cassava as an alternative starch media source. SpringerPlus, v. 2, n. 1, p. 579, 2013.

DE SILVA, N. I.; BROOKS, S.; LUMYONG, S.; HYDE, K. D. Use of endophytes as biocontrol agents. Fungal Biology Reviews, v. 33, n. 2, p. 133-148.

DRURY, H. The useful plants of India. William H. Allen, London. 1873.

FAETH, S. H.; FAGAN, W. F. Fungal endophytes: common host plant symbionts but uncommon mutualists. Integrative and Comparative Biology, v. 42, n. 2, p. 360-368, 2002.

FERREIRA, M. C.; VIEIRA, M. D. L. A.; ZANI, C. L.; DE ALMEIDA ALVES, T. M.; JUNIOR, P. A. S.; MURTA, S. M.; ROMANHA, A. J.; GIL, L. H. V. G. CARVALHO, A. G. DE O.; ZILLI, J. E.; VITAL, M. J. S.; ROSA, C. A.; ROSA, L. H. Molecular phylogeny, diversity, symbiosis and discover of bioactive compounds of endophytic fungi associated with the medicinal Amazonian plant Carapa guianensis Aublet (Meliaceae). Biochemical Systematics and Ecology, v. 59, p. 36-44, 2015.

GOVINDAPPA, M.; SADANANDA, T.; RAMACHANDRA, Y. L.; CHANDRAPPA, C. P.; RAI, P. S.; PRASAD, S. K. In vitro and in vivo antidiabetic activity of lectin ( $\mathrm{N}$-acetylgalactosamine, $64 \mathrm{kDa}$ ) isolated from endophytic fungi, Alternaria species from Viscum album on alloxan induced diabetic rats. Integrative Obesity \& Diabetes, v. 1, n. 1, p. 1119, 2015.

HANADA, R. E.; DE JORGE SOUZA, T.; POMELLA, A. W.; HEBBAR, K. P.; PEREIRA, J. O.; ISMAIEL, A.; SAMUELS, G. J. Trichoderma martiale sp. nov., a new endophyte from sapwood of Theobroma cacao with a potential for biological control. Mycological Research, v. 112, n. 11, p. 1335-1343, 2008.

HARDOIM, P. R.; VAN OVERBEEK, L. S.; BERG, G.; PIRTTILA, A. M.; COMPANT, S.; CAMPISANO, A.; DORING, M.; SESSITSCH, A. The hidden world within plants: Ecological and evolutionary considerations for defining functioning of microbial endophytes. Microbiology and Molecular Biology Reviews, v. 79, n. 3, p. 293-320, 2015. 
HIRUMA, K.; GERLACH, N.; SACRISTÁN, S.; NAKANO, R. T.; HACQUARD, S.; KRACHER, B.; NEUMANN, U.; RAMÍREZ, D.; BUCHER, M.; O'CONNELL, R. J.; SCHULZE-LEFERT, P. Root endophyte Colletotrichum tofieldiae confers plant fitness benefits that are phosphate status dependent. Cell, v. 165, n. 2, p. 464-474, 2016.

INTARAUDOM, C.; BOONYUEN, N.; SUVANNAKAD, R.; RACHTAWEE, P.; PITTAYAKHAJONWUT, P. Penicolinates A-E from endophytic Penicillium sp. BCC16054. Tetrahedron Letters, v. 54, n. 8, p. 744-748, 2013.

KAANICHE, F.; HAMED, A.; ABDEL-RAZEK, A. S.; WIBBERG, D.; ABDISSA, N.; EL EUCH, I. Z.; ALLOUCHE, N.; MELLOULI, L.; SHAABAN, M.; SEWALD, N. Bioactive secondary metabolites from new endophytic fungus Curvularia sp isolated from Rauwolfia macrophylla. PloS One, v. 14, n. 6, p. e0217627, 2019.

KOREJO, F.; ALI, S. A.; SHAFIQUE, H. A.; SULTANA, V.; ARA, J.; EHTESHAMUL-HAQUE, S. Antifungal and antibacterial activity of endophytic Penicillium species isolated from Salvadora species. Pakistan Journal of Botany, v. 46, n. 6, p. 2313-2318, 2014.

LACAZ, C. S.; PORTO, E.; VACCARI, E.M.H.; MELO,N. T. Guia para identificação de Fungos, Actinomicetos e Algas de interesse médico. São paulo: Sarvier, 1998, 445 p.

LIANG, H.; XING, Y.; CHEN, J.; ZHANG, D.; GUO, S.; WANG, C. Antimicrobial activities of endophytic fungi isolated from Ophiopogon japonicus (Liliaceae). BMC Complementary and Alternative Medicine, v. 12, n. 1, p. 238, 2012.

LIZCANO, L. J.; BAKKALI, F.; RUIZ-LARREA, M. B.; RUIZ-SANZ, J. I. Antioxidant activity and polyphenol content of aqueous extracts from Colombian Amazonian plants with medicinal use. Food Chemistry, v. 119, p. 1566-1570, 2010.

LOU, J.; FU, L.; PENG, Y.; ZHOU, L. Metabolites from Alternaria fungi and their bioactivities. Molecules, v. 18, n. 5, p. 5891-5935, 2013.

MACHADO, D. F. M.; PARZIANELLO, F. R.; SILVA, A. C. F. D.; ANTONIOLLI, Z. I. Trichoderma no Brasil: o fungo e o bioagente. Revista de Ciências Agrárias, v. 35, n. 1, p. 274-288, 2012.

MING, Q.; HAN, T.; LI, W.; ZHANG, Q.; ZHANG, H.; ZHENG, C.; HUANG, F.; RAHMAN, K.; QIN, L. Tanshinone IIA and tanshinone I production by Trichoderma atroviride D16, an endophytic fungus in Salvia miltiorrhiza. Phytomedicine, v. 19, n. 3-4, p. 330-333, 2012.

NUMPONSAK, T.; KUMLA, J.; SUWANNARACH, N.; MATSUI, K.; LUMYONG, S. Via biossintética e condições ideais para a produção de ácido indol-3-acético por um fungo endofítico, Colletotrichum fructicola CMU-A109. PloS One, v. 13, n. 10, p. e0205070, 2018.

OKI, Y.; SOARES, N.; BELMIRO, M. S.; CÔRREA JUNIOR, A.; FERNANDES, G. W. The influence of the endophytic fungi on the herbivores from Baccharis dracunculifolia (Asteraceae). Neotropical Biology and Conservation, v. 4, n. 2, p. 83-88, 2009. 
OLIVEIRA, A. H. Atividade antimicrobiana e imunológica in vitro dos extratos de Senna reticulata (Willd). Irwin \& Barneby (mata-pasto) e Vismia guianensis (Aubl.) (lacre). 2009. 126 f. Dissertação de Mestrado, UNESP. Araraquara, 2009.

OTERO, J. T.; ACKERMAN, J. D.; BAYMAN, P. Diversity and host specificity of endophytic Rhizoctonia-like fungi from tropical orchids. American Journal of Botany, v. 89, n. 11, p. 1852-1858, 2002.

PAROLIN, P. Floristic composition and structure of two stands of Senna reticulata differing in age. Amazoniana: Limnologia et Oecologia Regionalis Systematis Fluminis Amazonas, v. 15, n. 1/2, p. 113-128, 1998.

PAROLIN, P. Senna reticulata, a pioneer tree from Amazonian várzea floodplains. The Botanical Review, v. 67, n. 2, p. 239-254, 2001.

PAROLIN, P.; OLIVEIRA, A. C.; PIEDADE, M. T. F.; WITTMANN, F.; JUNK, W. J. Pioneer trees in Amazonian floodplains: three key species form monospecific stands in different habitats. Folia Geobotanica, v. 37, n. 2, p. 225-238, 2002.

PAROLIN, P. Fugitive and possessive establishment strategies in Amazonian floodplain pioneers. Flora, v. 198, p. 436- 443, 2003.

PAROLIN, P. Senna reticulata (Willd.) H.S. Irwin \& Barneby (Fabaceae) as "Pasture Killer" ("Matapasto") Pioneer tree in Amazonian floodplains. Ecologia Aplicada, v. 4, p. 41- 46, 2005.

PETERS, L. P.; PRADO, L. S.; SILVA, F. I.; SOUZA, F. S.; CARVALHO, C. M. Selection of endophytes as antagonists of Colletotrichum gloeosporioides in açaí palm. Biological Control, v.150, p. 104350, 2020.

PHOTITA, W.; LUMYONG, S.; LUMYONG, P.; HYDE, K. D. Endophytic fungi of wild banana (Musa acuminata) at doi Suthep Pui National Park, Thailand. Mycological Research, v. 105, n. 12, p. 1508-1513, 2001.

POPLI, D.; ANIL, V.; SUBRAMANYAM, A.B.; NM, N.; VR, R., RAO, S. N.; RAI, R. V.; GOVINDAPPA, M. Endophyte fungi, Cladosporium species-mediated synthesis of silver nanoparticles possessing in vitro antioxidant, anti-diabetic and anti-Alzheimer activity. Artificial Cells, Nanomedicine, and Biotechnology, v. 46, n. sup1, p. 676-683, 2018.

POWTHONG, P. JANTRAPANUKORN, B.; THONGMEE, A.; SUNTORNTHITICHAROEN, $P$. Screening of Antimicrobial Activities of the Endoph ytic Fungi Isolated from Sesbania grandiflora (L.). Journal of Agricultural Science and Technology, v. 15, p. 1513-1522, 2013

RAGHUNATH, R.; RADHAKRISHNA, A.; ANGAYARKANNI, J.; PALANISWAMY, M. Production and cytotoxicity studies of lovastatin from Aspergillus niger PN2 an endophytic fungi isolated from Taxus baccata. International Journal of Applied Biology and Pharmaceutical, v. 3, p. $342-351,2012$. 
RANGANATHAN, N.; MAHALINGAM, G. Secondary metabolite as therapeutic agent from endophytic fungi Alternaria longipes strain VITN14G of mangrove plant Avicennia officinalis. Journal of Cellular Biochemistry, v. 120, n. 3, p. 4021-4031, 2019.

RIBEIRO, J. G.; SERRA, I. M. R. de S.; ARAÚJO, M. U. P. Uso de produtos naturais no controle de antracnose causado por Colletotrichum gloeosporioides em mamão. Summa Phytopathologica, v. 42, n. 2, p. 160-164, 2016.

SANTOS, R. N. dos; SILVA, M. G. de V.; BRAZ FILHO, R. Constituintes químicos do caule de Senna reticulata Willd.(Leguminoseae): Chemical constituents isolated from the wood of Senna reticulata Willd. Química Nova, v. 31, n. 8, p. 1979-1981, 2008.

SCHUSTER, A.; SCHMOLL, M. Biology and biotechnology of Trichoderma. Applied Microbiology and Biotechnology, v. 87, n. 3, p. 787-799, 2010.

SHENTU, X.; ZHAN, X.; MA, Z.; YU, X.; ZHANG, C. Antifungal activity of metabolites of the endophytic fungus Trichoderma brevicompactum from garlic. Brazilian journal of microbiology, v. 45, n. 1, p. 248-254, 2014.

SIA, E. de F. Meios de cultura alternativos para fungos utilizando diferentes substratos, especialmente de mandioca (Manihot esculenta). Tese (Doutorado em Biotecnologia), Universidade Federal do Amazonas, Manaus, 2012.

SIEBER, T. N.; DORWORTH, C. E. An ecological study about assemblages of endophytic fungi in Acer macrophyllum in British Columbia: in search of candidate mycoherbicides. Canadian Journal of Botany, v. 72, n. 10, p. 1397-1402, 1994.

SILVA, M. S. B. D. S.; RODRIGUES, A. A. C.; OLIVEIRA, L. D. J. M. G. D.; SILVA, E. K. C.; PEREIRA, T. D. S. Sanidade de sementes de arroz, biocontrole, caracterização e transmissão de Curvularia lunata em semente-plântula de arroz. Revista Ceres, v. 61, n. 4, p. 511-517, 2014.

SINGH, B.; THAKUR, A.; KAUR, S.; CHADHA, B. S.; KAUR, A. Acetylcholinesterase inhibitory potential and insecticidal activity of an endophytic Alternaria sp. from Ricinus communis. Applied biochemistry and biotechnology, v. 168, n. 5, p. 991-1002, 2012.

STIERLE, A.; STROBEL, G.; STIERLE, D. Taxol and taxane production by Taxomyces andreanae, an endophytic fungus of Pacific yew. Science, v. 260, n. 5105, p. 214-216, 1993.

VENKATESWARULU, N.; SHAMEER, S.; BRAMHACHARI, P. V.; BASHA, S. T.; NAGARAJU, C.; VIJAYA, T. Isolation and characterization of plumbagin (5-hydroxyl-2methylnaptalene-1, 4-dione) producing endophytic fungi Cladosporium delicatulum from endemic medicinal plants. Biotechnology Reports, v. 20, p. e00282, 2018.

VIGNERON, M.; DEPARIS, X.; DEHARO, E.; BOURDY, G. Antimalarial remedies in French Guiana: A knowledge attitudes and practices study. Journal of Ethnopharmacology, v. 98, p. 351-360, 2005. 
WAQAS, M.; KHAN, A. L.; HAMAYUN, M.; SHAHZAD, R.; KANG, S. M.; KIM, J. G.; LEE, I. J. Endophytic fungi promote plant growth and mitigate the adverse effects of stem rot: an example of Penicillium citrinum and Aspergillus terreus. Journal of Plant Interactions, v. 10, n. 1 , p. $280-287,2015$.

YADAV, M.; YADAV, A.; YADAV, J. P. In vitro antioxidant activity and total phenolic content of endophytic fungi isolated from Eugenia jambolana Lam. Asian Pacific Journal of Tropical Medicine, v. 7, p. 256-261, 2014.

YAN, X. N.; SIKORA, R. A.; ZHENG, J. W. Potential use of cucumber (Cucumis sativus L.) endophytic fungi as seed treatment agents against root-knot nematode Meloidogyne incognita. Journal of Zhejiang University Science B, v. 12, n. 3, p. 219-225, 2011.

ZHANG, H. W.; SONG, Y. C.; TAN, R. X. Biology and chemistry of endophytes. Natural Product Reports, v. 23, n. 5, p. 753-771, 2006.

ZHANG, P.; ZHOU, P. P.; YU, L. J. An endophytic taxol-producing fungus from Taxus media, Cladosporium cladosporioides MD2. Current Microbiology, v. 59, n. 3, p. 227, 2009. 